\title{
Met Éireann high resolution reanalysis for Ireland
}

\author{
Emily Gleeson, Eoin Whelan, and John Hanley \\ Research, Environment and Applications Division, Met Éireann, Dublin, Ireland \\ Correspondence to: Emily Gleeson (emily.gleeson@met.ie)
}

Received: 20 December 2016 - Revised: 16 March 2017 - Accepted: 17 March 2017 - Published: 29 March 2017

\begin{abstract}
The Irish Meteorological Service, Met Éireann, has carried out a 35 -year very high resolution ( $2.5 \mathrm{~km}$ horizontal grid) regional climate reanalysis for Ireland using the ALADIN-HIRLAM numerical weather prediction system. This article provides an overview of the reanalysis, called MÉRA, as well as a preliminary analysis of surface parameters including screen level temperature, $10 \mathrm{~m}$ wind speeds, mean sea-level pressure (MSLP), soil temperatures, soil moisture and $24 \mathrm{~h}$ rainfall accumulations. The quality of the 3-D variational data assimilation used in the reanalysis is also assessed. Preliminary analysis shows that it takes almost 12 months to spin up the deep soil in terms of moisture, justifying the choice of running year-long spin up periods. Overall, the model performed consistently over the time period. Small biases were found in screen-level temperatures (less than $-0.5^{\circ} \mathrm{C}$ ), MSLP (within $0.5 \mathrm{hPa}$ ) and $10 \mathrm{~m}$ wind speed (up to $0.5 \mathrm{~m} \mathrm{~s}^{-1}$ ) Soil temperatures are well represented by the model. $24 \mathrm{~h}$ accumulations of precipitation generally exhibit a small positive bias of $\sim 1 \mathrm{~mm}$ per day and negative biases over mountains due to a mismatch between the model orography and the geography of the region. MÉRA outperforms the ERA-Interim reanalysis, particularly in terms of standard deviations in screen-level temperatures and surface winds. This dataset is the first of its kind for Ireland that will be made publically available during spring 2017.
\end{abstract}

\section{Introduction}

Climate reanalyses are an important source of information for monitoring climate and for the validation and calibration of numerical weather prediction (NWP) models but also have vast uses outside of meteorology and climatology. Because they are carried out using a fixed version of a forecast model and a data assimilation system which utilises historical observations, they produce parameters that are physically consistent and often not routinely observed. Thus, climate reanalyses have the potential to extend the knowledge gained from current observation networks.

Atmospheric reanalyses originated with the production of datasets by ECMWF and GFDL for the 1979 Global Weather Experiment (Fleming et al., 1979). Since then, the production of global datasets has evolved with many being updated close to real time (e.g. ERA-Interim (Dee et al., 2011, 1979present, $\sim 79 \mathrm{~km}$ ), JRA-55 (Kobayashi et al., 2015, 1958present, $\sim 65 \mathrm{~km}$ ), the Modern-Era Retrospective Analysis for Research and Applications (MERRA (Rienecker et al., 2011, 1979-present, $\sim 60 \mathrm{~km}$ ), the NCEP/NCAR global re- analysis (Kalnay et al., 1996, 1957-1996, $210 \mathrm{~km}$ ) and the ERA-40 global reanalysis (Uppala et al., 2005, 1957-2002, $\sim 125 \mathrm{~km})$ ).

More recent global reanalyses use atmosphere-land-ocean coupled systems or earth system models (e.g. ECMWF's ERA-20C and ERA-20CM (Hersbach et al., 2013; Poli et al., 2013, 1900-2010, 125 km)). ECMWF's latest reanalysis product ERA5 (Hersbach and Dee, 2016, 1979-present, $\sim 31 \mathrm{~km}$ ) has entered production. Although not coupled to an ocean model, it is more advanced in other ways: uncertainty is estimated using a 10-member ensemble for data assimilation, it contains CMIP5 (Taylor et al., 2012) greenhouse gas concentrations, volcanic eruptions, SSTs and sea-ice concentrations and additional observations and satellite data.

Due to computational constraints global reanalyses cannnot be run at the very high resolutions required to resolve mesoscale processes but are generally used to provide boundary conditions for regional reanalyses. The advantage of regional reanalyses is that they can be run at high temporal and spatial resolution so that focus can be put on near surface parameters, extremes and frequency distributions. 


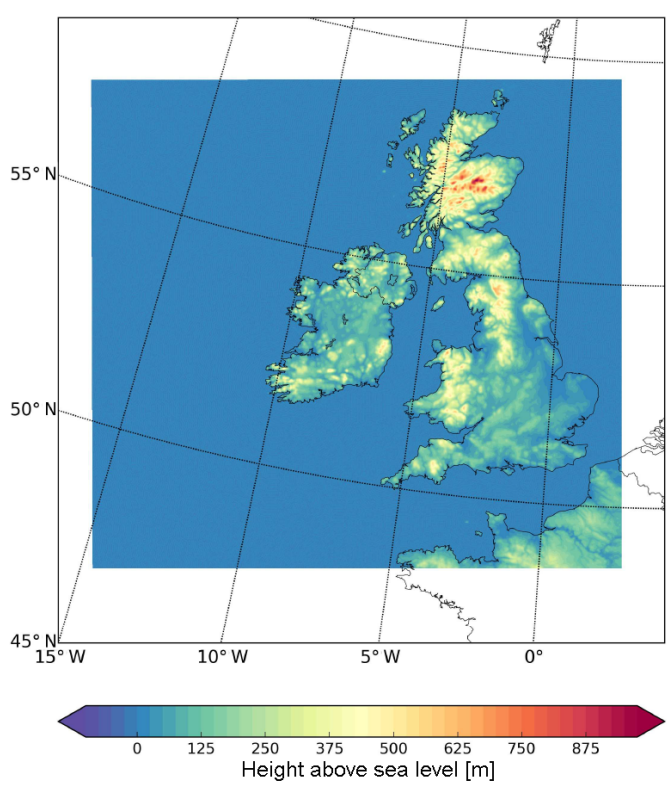

(a)

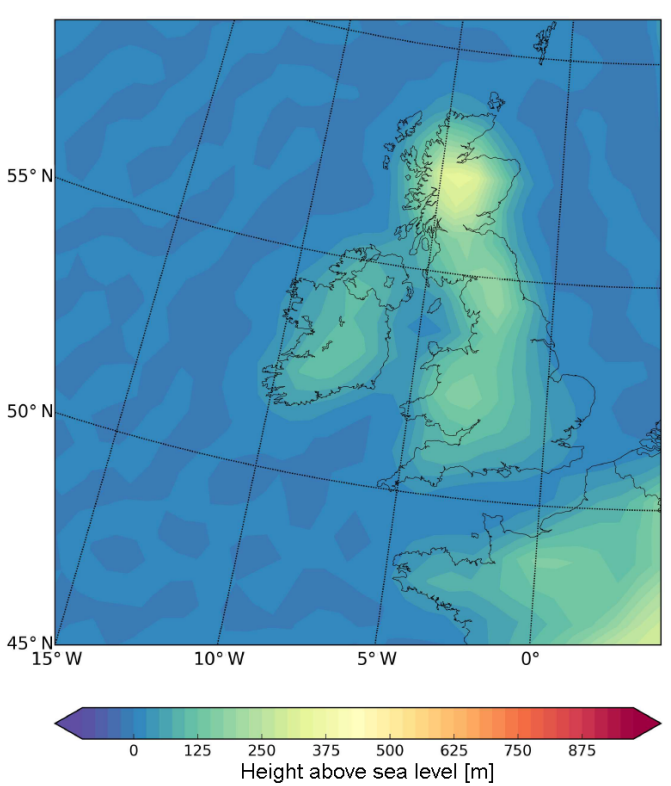

(b)

Figure 1. (a) MÉRA (2.5 km grid spacing) and (b) ERA-Interim (79 km grid spacing) orographies. Over sea grid-points the geopotential fields used to plot the model orographies show "spectral ripples", which are a reflection of the fact that the ERA-Interim and HARMONIE models are defined in spectral space.

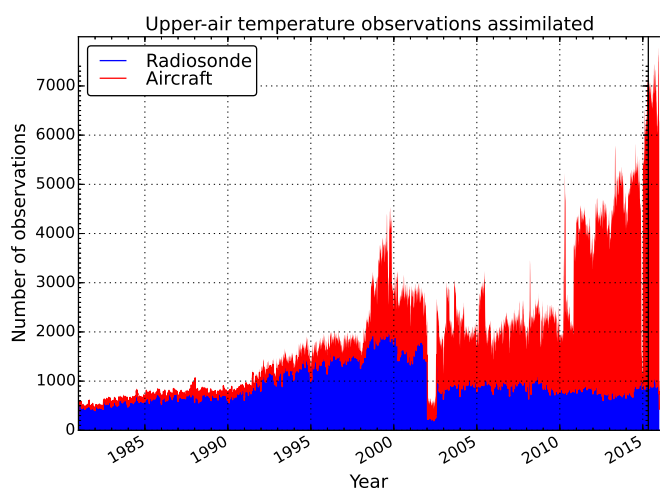

(a)

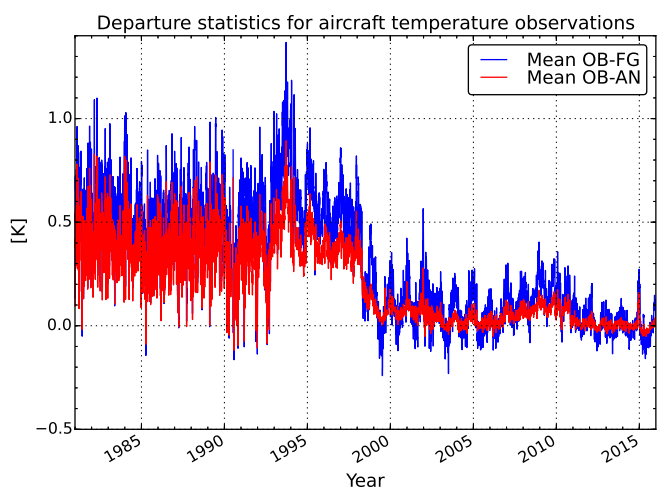

(b)

Figure 2. (a) Time-series of the number of upper-air temperature observations used by the 3D-Var data assimilation system in HARMONIEAROME. (b) Time-series of average first-guess (OB-FG) and analysis (OB-AN) departure statistics for aircraft temperature observations assimilated by HARMONIE-AROME where mean OB-FG values are shown in blue and mean OB-AN values are shown in red. A 7-day running average is used in (a) and (b) for the period 1981-2014.

Several regional reanalyses have already been produced including, for example, the Arctic Reanalysis ASR (Bromwich et al., 2010, 2000-2010, 30 km), the Baltic Sea reanalysis (Luhamaa et al., 2011, 1965-2005, $11 \mathrm{~km}$ ), COSMO-REA6 (Bollmeyer et al., 2015, 1997-2004, 6 km), the HIRLAM reanalysis (Dahlgren et al., 2016, 1979-2014, $\sim 22 \mathrm{~km}$ ), the North American Regional Reanalysis (Mesinger et al., 2006, 1979-2003, $\sim 32 \mathrm{~km}$ ) and the South Asian Regional Reanalysis (Kar et al., 2016, 1998-2002, 30 km) among many others. The EU European Reanalysis and Observations for
Monitoring project (EURO4M: Klein Tank, 2010) combined results from several model-based European regional reanalyses as well as observations from satellites and ground-based stations. Its successor, the ongoing FP7 (Framework Programme 7) funded reanalysis project, UERRA (Uncertainties in Ensembles of Regional ReAnalyses; UERRA, 2017), will include the recovery of historical data and the estimation of uncertianties in reanalyses.

Despite the abundance of reanalyses for Europe, no very high resolution dataset has been produced for Ireland. To ad- 


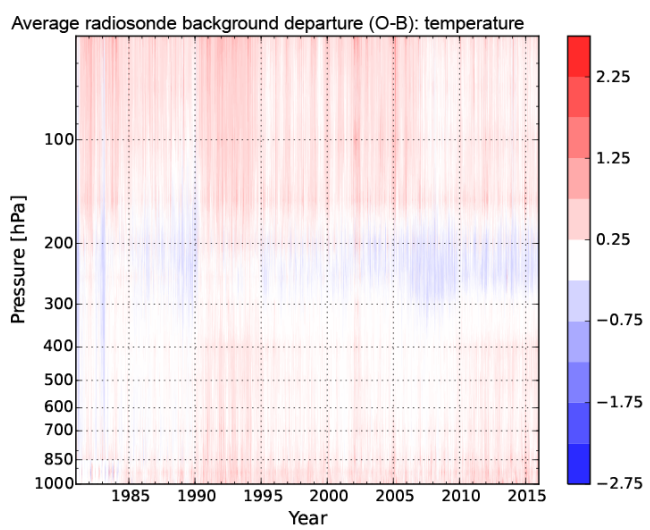

(a)

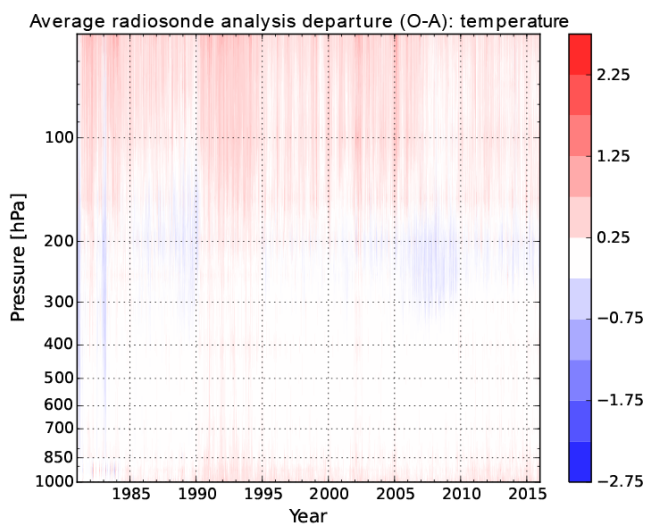

(b)

Figure 3. Time-series of (a) first-guess (O-B) and (b) analysis (O-A) departure statistics for radiosonde temperature observations assimilated by HARMONIE-AROME at a selection of standard pressure levels. A 7-day running average is used in (a) and (b) for the period 1981-2014.
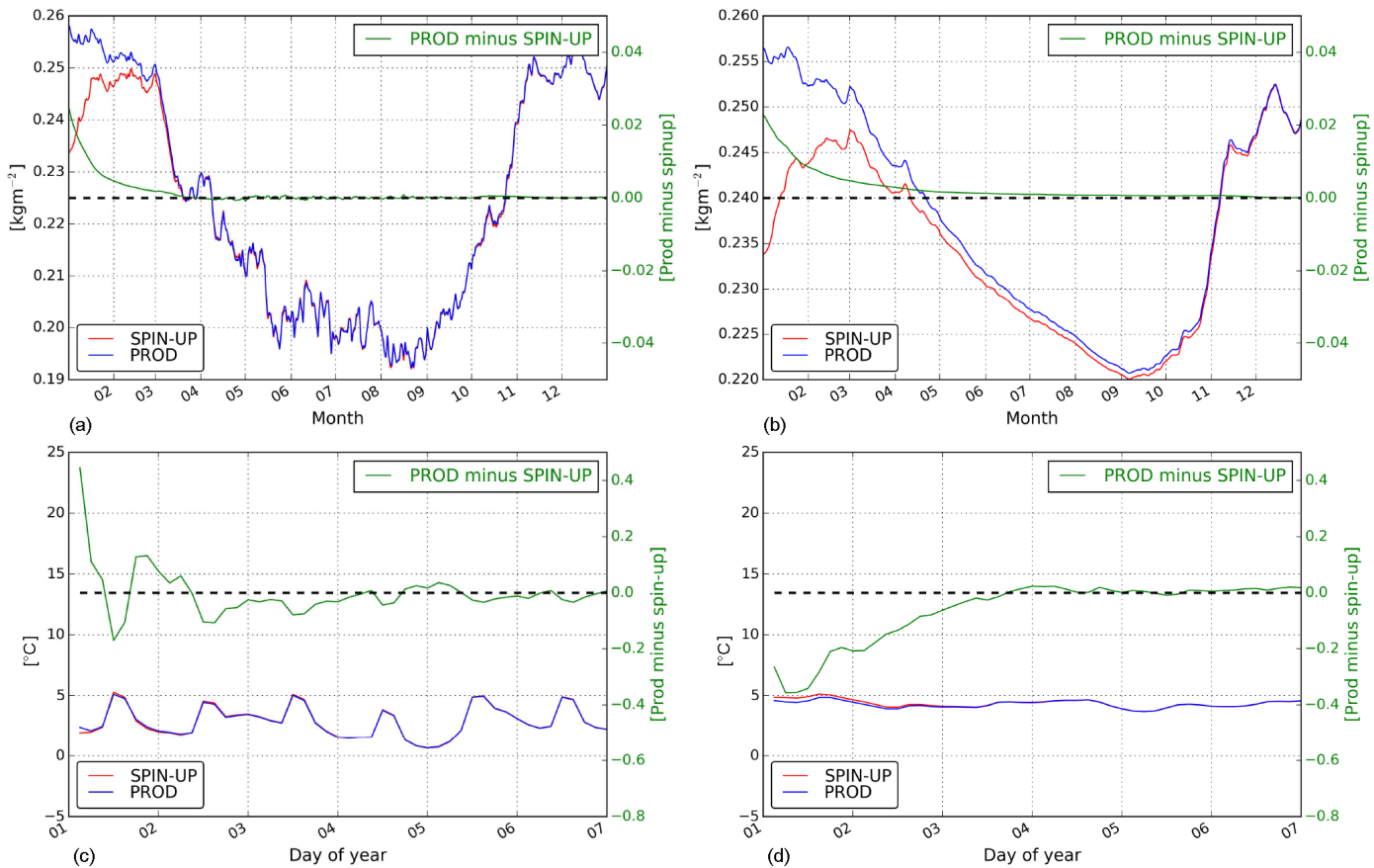

Figure 4. Spin-up soil moisture (red) compared with production soil moisture (blue) for (a) $20 \mathrm{~cm}$ below the surface and (b) $300 \mathrm{~cm}$ below the surface. The comparison includes the years 2000, 2005 and 2010. (c) and (d) are similar but show soil temperature at the surface and $20 \mathrm{~cm}$ below the surface. As soil temperatures spin-up quickly only days 1 to 7 are shown. In each subplot the production versus spin-up differences are shown in green.

dress this, we have run the HARMONIE-AROME canonical configuration of the ALADIN-HIRLAM system on a $2.5 \mathrm{~km}$ horizontal grid for the 35-year period 1981-2015 forced by ERA-Interim lateral boundary conditions, with the aim of improving our knowledge of surface parameters and extremes. Inspiration for this project came from KNMI's production of a 35-year wind atlas for the North Sea (KNWatlas; 1997-2013; Stepek et al., 2015) which was also produced using the ALADIN-HIRLAM system. The Irish re- analysis dataset, called MÉRA (Met Éireann ReAnalysis) will extend the knowledge gained from observations as the model grid is much finer than observational coverage over Ireland. It was carried out using the same domain as has been used operationally by Met Éireann since 2011. Centred over the Island of Ireland, the domain covers Ireland, the United Kingdom and an area of northern France, see Fig. 1a. The extra topographical information gained by using the $2.5 \mathrm{~km}$ grid 


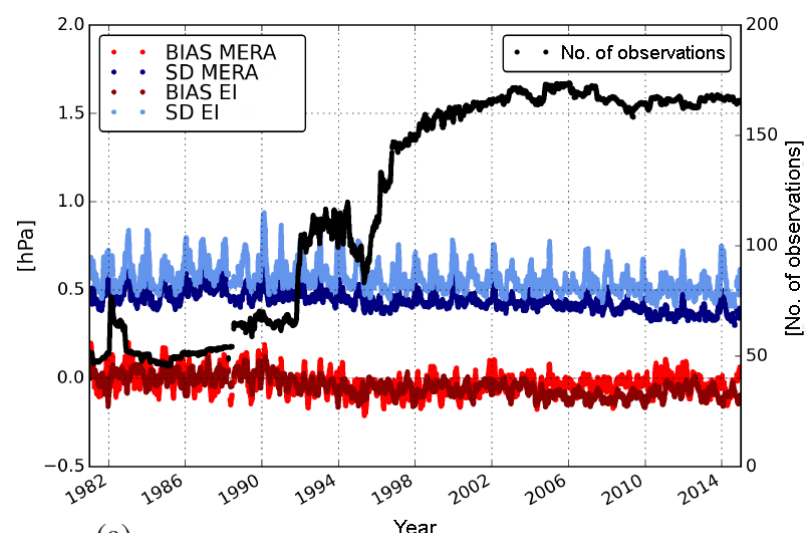

(a)

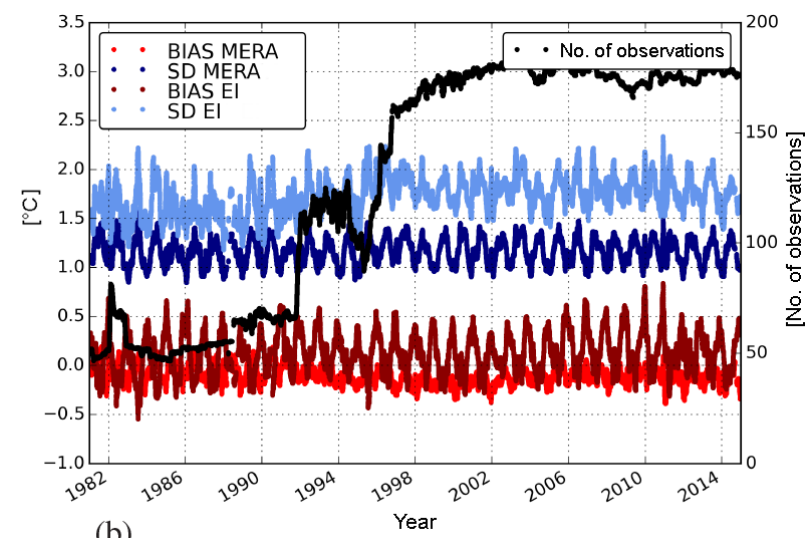

(b)

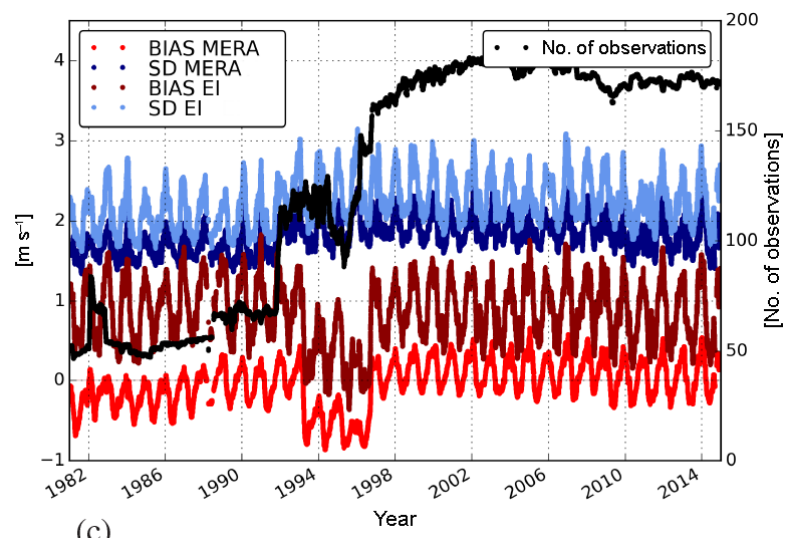

(c)

Figure 5. Time-series of verification scores for MÉRA and ERAInterim $3 \mathrm{~h}$ forecasts of (a) MSLP, (b) $2 \mathrm{~m}$ temperature, (c) $10 \mathrm{~m}$ wind speed compared with SYNOP observations. The average error, or bias, is shown in red (MÉRA) and maroon (ERA-Interim) and the standard deviation of the errors is shown in navy (MÉRA) and light blue (ERA-Interim). A 1-month running average is applied to the data.

is clear when compared with the ERA-Interim grid $(\sim 79 \mathrm{~km}$, Fig. 1b). MÉRA data will be available for use in Spring 2017.

This paper provides an overview of the MÉRA project including the shared ALADIN-HIRLAM system, the data assimilation methods, the observations used and an initial evaluation. It is laid out as follows. Section 2 provides details
Table 1. HARMONIE-AROME configuration used for MÉRA.

\begin{tabular}{|c|c|}
\hline Model version & HARMONIE-AROME 38h1.2 \\
\hline Domain & $540 \times 500$ grid points $(\Delta x=2.5 \mathrm{~km})$ \\
\hline Vertical levels & 65 levels up to $10 \mathrm{hPa}$, first level at $12 \mathrm{~m}$ \\
\hline Forecast cycle & $3 \mathrm{~h}$ \\
\hline Data assimilation & $\begin{array}{l}\text { Optimal interpolation for surface parameters } \\
\text { 3D-Var assimilation for upper air parameters }\end{array}$ \\
\hline Observations & $\begin{array}{l}\text { Pressure from SYNOP, SHIP and DRIBU } \\
\text { Temperature and winds from AIREP and AMDAR } \\
\text { Winds from PILOT } \\
\text { Temperature,winds and humidity from TEMP }\end{array}$ \\
\hline Forecast & $3 \mathrm{~h}$ forecasts, but a $33 \mathrm{~h}$ forecast at $00: 00 \mathrm{Z}$ \\
\hline
\end{tabular}

on the model configuration and MÉRA simulations. Section 3 focusses on the data assimilation system. Results of the spin-up simulations and verification of surface parameters are given in Sect. 4 with discussions and conclusion in Sect. 5 .

\section{MÉRA: model configuration and simulation details}

Details regarding the HARMONIE-AROME model configuration and data assimilation system are given in Sect. 2.1; information on the simulations is provided in Sect. 2.2.

\subsection{Model Configuration}

The harmonie-38h1.2 version of ALADIN-HIRLAM system was used to carry out the MÉRA simulations. This canonical configuration of HARMONIE-AROME was run on a horizontal grid of $2.5 \mathrm{~km}$ spacing, using 65 vertical levels and a model top of $10 \mathrm{hPa}$. The data assimilation component of the model is described in Fischer et al. (2005) and Brousseau et al. (2011); the forecast component is described in Seity et al. (2011) with more recent updates included in Bengtsson et al. (2017). The SURFEX externalised surface scheme (Masson et al., 2013) is used for surface data assimilation and the modelling of surface processes. A summary of the model details is presented in Table 1.

Conventional observations (i.e. from synoptic stations, ships, buoys, radiosonde ascents and aircraft) were assimilated. These observations are the same as those used by the European Centre for Medium Range Weather Forecasts' (ECMWF) ERA-Interim reanalysis. Locally available SYNOP observations were used to fill gaps in the ERAInterim SYNOP observation archive to ensure cycle continuity and successful data assimilation each cycle. MÉRA uses a $3 \mathrm{~h}$ forecast cycle with surface and upper-air data assimilation (cf. Sect. 3). Three-hour forecasts were produced for each cycle except the midnight $(00: 00 \mathrm{Z})$ cycle when a $33 \mathrm{~h}$ forecast was produced. This provides a precipitation forecast each day that can be evaluated using locally available observations of daily accummulations of precipitaion. The $33 \mathrm{~h}$ forecast was deemed necessary in order to avoid the nega- 
Table 2. Summary of output available on pressure, height and sub-surface levels.

\begin{tabular}{lll}
\hline Level type & Parameters & Levels \\
\hline Pressure & Temperature, wind, cloud, & $100,200,300,400,500,600$, \\
& relative humidity, geopotential & $700,800,850,900,925,950,1000 \mathrm{hPa}$ \\
Height above ground & Temperature, wind, relative humidity & $30,50,60,70,80,90,100,125$, \\
& & $150,200,300,400 \mathrm{~m}$ \\
Sub-surface & Temperature, moisture, ice & $0,20,300 \mathrm{~cm}$ (below the surface) \\
Surface & Precipitation diagnostics & Surface \\
Diagnostic & Screen level parameters & 2 m for temperatures and $10 \mathrm{~m}$ for winds and gusts \\
Surface & Radiative and non-radiative fluxes & Surface \\
Top of atmosphere & Radiative and non-radiative fluxes & Nominal top of atmosphere \\
\hline
\end{tabular}

tive impact of model spin-up on the quality of short-range (3-4 h) precipitation forecasts. It is generally acknowledged that model spin-up, in terms of precipitation, is of the order of a few hours (e.g. Kasahara et al., 1992). A more detailed analysis of this, in the context of MÉRA, is currently underway.

No significant changes were applied to the default HARMONIE-AROME data assimilation or forecast configurations used by the MÉRA project. However, some tuning of the surface drag coefficient, $C_{\mathrm{D}}$, used by SURFEX, was carried out following correspondence with Xiaohua Yang, personal communication, (2014). Comparisons of forecast winds and gusts with equivalent observations were used to evaluate the quality of near surface winds. Based on the verification results from a series of month-long sensitivity tests, $C_{\mathrm{D}}$ was changed from a value of 0.01 to 0.025 .

\subsection{Simulation Details}

ERA-Interim model-level analysis and forecast data were used for the HARMONIE-AROME lateral boundary conditions (LBC). The ERA-Interim IFS configuration uses a T255 spherical-harmonic representation for dynamical fields, a reduced Gaussian grid with a horizontal grid spacing of approximately $79 \mathrm{~km}$ for surface fields, and 60 vertical levels with a model top at $0.1 \mathrm{hPa}$. Information from the ERAInterim LBCs is read by the HARMONIE-AROME forecast model every $3 \mathrm{~h}$ using one-way nesting. The downscaling ratio, the ratio of the driving model grid spacing to the limited area model (LAM) grid spacing, is approximately $32: 1$. Ideally, the resolution of the LBC grid spacing and the LAM grid spacing should be as close as possible (Warner et al., 1997) to avoid the problem of reflections at outflow boundaries when there is a mismatch in grid spacings as discussed in Harris and Durran (2010). Davies (2013) showed that errors are small and confined to the boundaries for downscaling ratios of up to $4: 1$. Global climate simulations have been successfully downscaled using a downscaling factor of 17 (Hollweg et al., 2008). In addition, recent projects to produce an extreme wind climatology for The Netherlands (Burgers et al., 2013) and a wind/wave climatology for Ireland (Gallagher et al., 2016) using ERA-Interim and HARMONIE-AROME have shown that the approach taken in this study, i.e. nesting HARMONIE-AROME directly with ERA-Interim LBCs, is effective.

Seven separate simulations were set up to run for five years at a time, with a one year spin-up period for each simulation. We therefore have 6 spin-up years $(1985,1990,1995$, $2000,2005,2010)$ that overlap with corresponding production years, which were used to evaluate the spin-up process of sub-soil parameters. A spin-up period of 1 year was deemed necessary to allow deep soil parameters to reach an equilibrium (cf. Sect. 4.1). Each simulation was run on ECMWF's Cray XC30 system, cca. The output data are, temporarily, stored in ECMWF's data handling system, ECFS. The project has produced approximately $750 \mathrm{~TB}$ of forecast and observation feedback data, $200 \mathrm{~TB}$ of which will be archived, with the forecast data stored as GRIB files and the observation feedback as ODB files. MÉRA will continue to be updated in real-time.

Three-hourly analysis output is available. Forecast model output is available for each forecast hour up to $33 \mathrm{~h}$ for the 00:00 $\mathrm{Z}$ forecast and to $3 \mathrm{~h}$ otherwise. A small subset of the surface (SURFEX) output is available at analysis times and for each $3 \mathrm{~h}$ forecast while upper-air data are available on pressure levels and a selection of near-surface levels. The analysis and forecast output data are summarised in Table 2.

\section{Data Assimilation}

Data assimilation is used to estimate the initial conditions of the surface and the atmosphere for the HARMONIEAROME forecast model using meteorological observations and a background field provided by short-range forecasts.

The surface data assimilation produces an analysis using optimum interpolation (OI), a weighted least squares fit to observations and a background field. CANARI (Code d'Analyse Nécessaire á ARPEGE pour ses Rejets et son Initialisation; Taillefer, 2002), is used to calculate analysis increments at each grid-point. The SURFEX OI data assimilation scheme is then used to adjust the soil moisture and tem- 


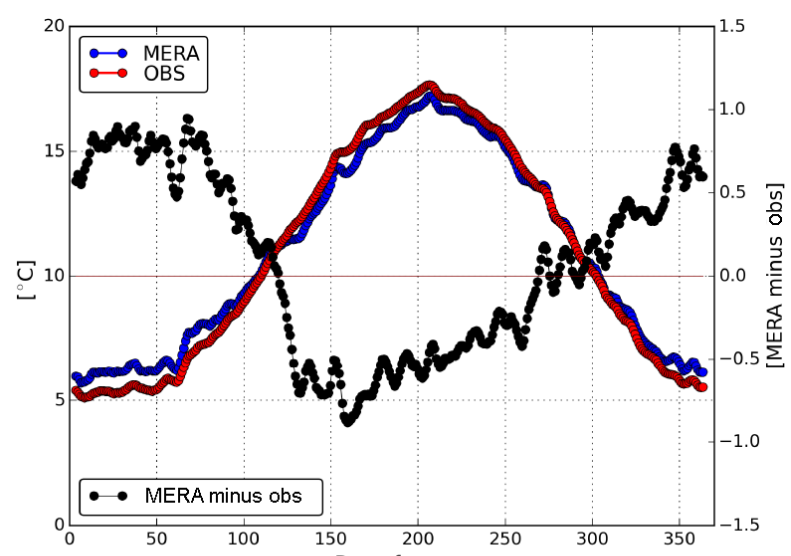

(a)
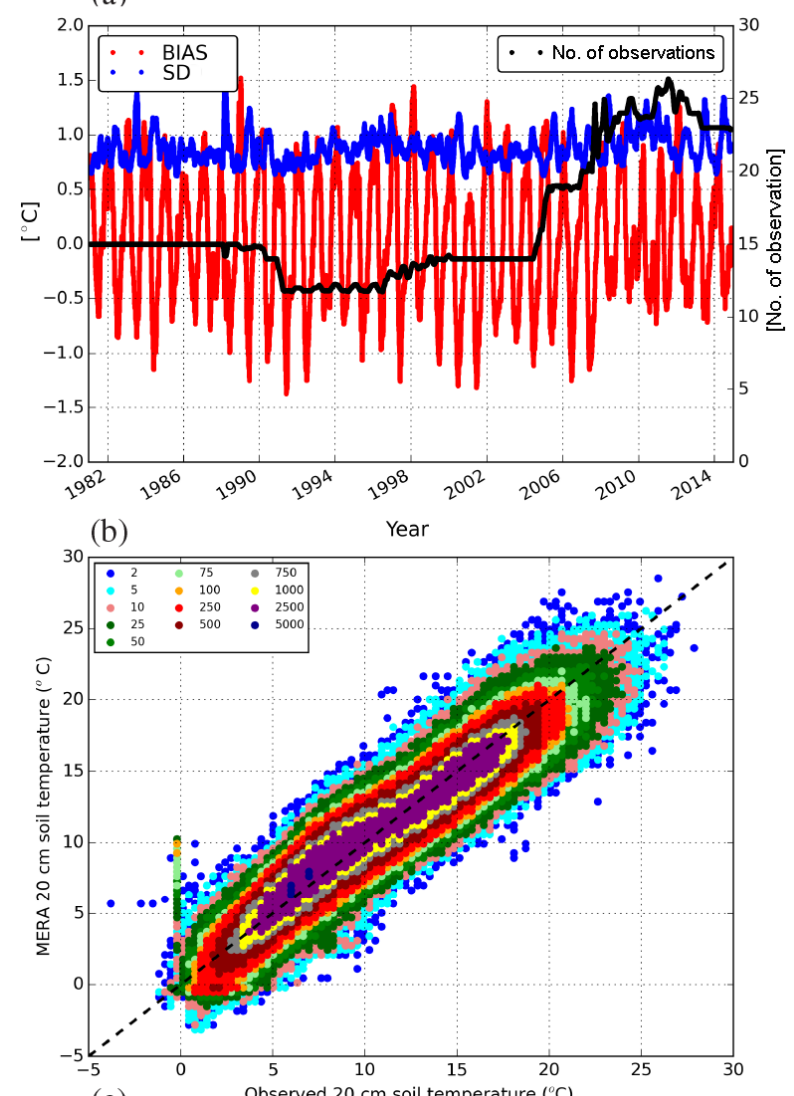

(c)

Figure 6. MÉRA and observed soil temperature $20 \mathrm{~cm}$ below the surface for the period 1981-2014. (a) Soil temperature by day of year, (b) time series where a 2-month running average is applied, (c) scatter plot of observed versus MÉRA soil temperatures (colours are indicative of the number of observations).

perature in the uppermost two levels of the surface. A snow analysis is carried for each 06:00 Z cycle by the CANARI OI scheme. Sea surface temperatures and sea ice concentrations are taken directly from the ERA-Interim LBCs.

Three dimensional variational data assimilation (3D-Var) is used to produce the most likely state of the atmosphere, i.e. the analysis, by minimising a cost function - the sum of devi- ations of the analysis from observations and deviations of the analysis from the background field, weighted by respective errors as in Fischer et al. (2005). The data assimilation cycle in MÉRA is carried out every $3 \mathrm{~h}$ using the $3 \mathrm{~h}$ forecast from the previous cycle and observations combined with error covariance information. The climatological background error covariances, generally referred to as structure functions, used in the cost function calculation were derived using an ensemble of HARMONIE-AROME forecasts as in Berre (2000). Forecasts were produced once per day for a 1-month period by downscaling four ECMWF Ensemble Data Assimilation members. Differences between the $6 \mathrm{~h}$ HARMONIEAROME forecasts were used to derive the structure functions. This was the recommended approach for the ALADINHIRLAM system at the start of the MÉRA project. It has been since noted that the derivation of structure functions would benefit from forecast data sampling both daily and seasonal variations; i.e. by using forecast data spanning the diurnal cycle and from different seasons. Also, longer forecast integrations may be required to produce more realistic convective-scale spectra as noted in Sánchez Arriola et al. (2016). Observation error covariances are prescribed in the observation preparation process.

Conventional observations are assimilated using the HARMONIE-AROME 3D-Var data assimilation system. In this a minimisation is followed by a blending process whereby the large scales produced by the analysis are combined with the meso-scale features available in the background field. This process is repeated every $3 \mathrm{~h}$ for each forecast cycle. Figure 2a shows data counts of the number of upper-air temperature observations used by the 3D-Var for the years 1981 up to the end of 2015. During this period there is a notable increase in the number of aircraft observations. However, there were also sharp drops in the numbers of upper-air observations available for assimilation during 2003 and December 2014.

The difference between observation values $(\mathrm{OB})$ and the equivalent first-guess (short-range forecast) values (FG) used by 3D-Var (i.e. the first-guess departures) are used to monitor and assess the quality of the MÉRA data assimilation. The 3D-Var minimization process should produce an analysis (AN) which is closer to the observations than the model background. The departures for aircraft observations are shown in Fig. $2 b$ for the same period as the data count plots in Fig. 2a. It is clear that OB-AN is closer to zero than OB-FG. An improvement in the average upper-air temperature departures is noticeable from around 2000 onwards due to the significant increase in the number of (AMDAR) aircraft observations available for assimilation. The improvement in upper-air temperature analyses can also be seen when radiosonde observations are compared with model first-guess values and analysis values. Figure 3 shows a time-series of average temperature OB-FG (Fig. 3a) and OB-AN (Fig. 3b) profiles for the years 1981-2015. There is a noticeable im- 


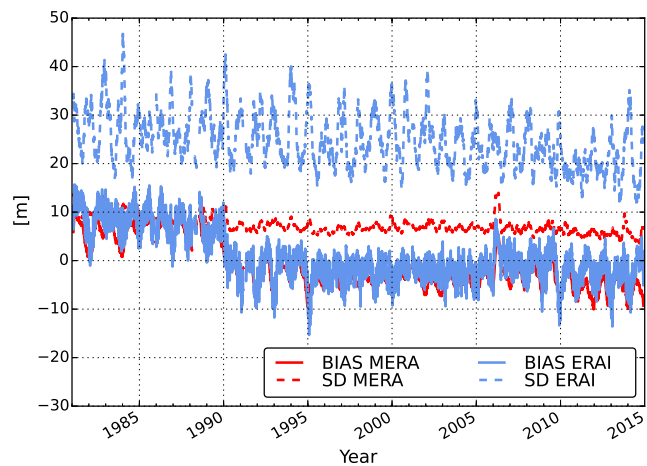

(a)

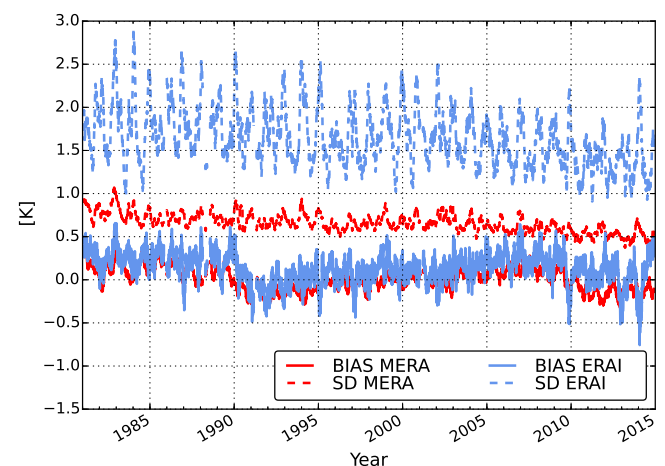

(b)

Figure 7. Time-series of verification scores for MÉRA and ERA-Interim $12 \mathrm{~h}$ forecasts of (a) geopotential and (b) temperature compared with radiosonde observations at $500 \mathrm{hPa}$. The average error, or bias, is shown as dashed lines for both MÉRA and ERA-Interim. The standard deviation of the errors is shown as continuous lines. A 2-month running average is applied to the data.

Daily mean bias (MAM)
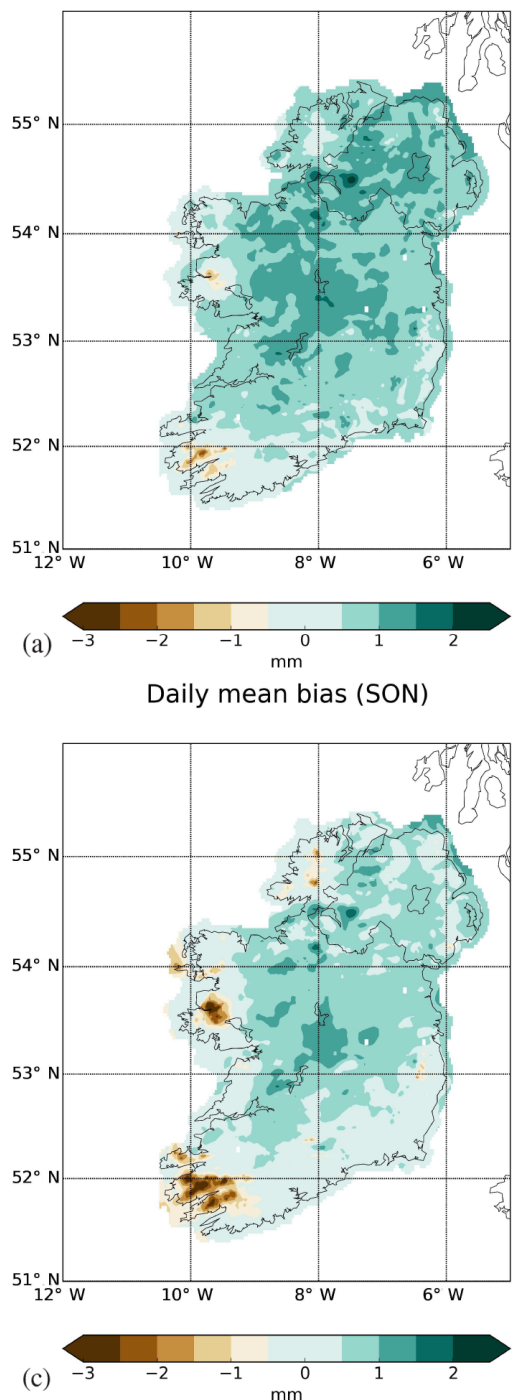

Daily mean bias (JJA)

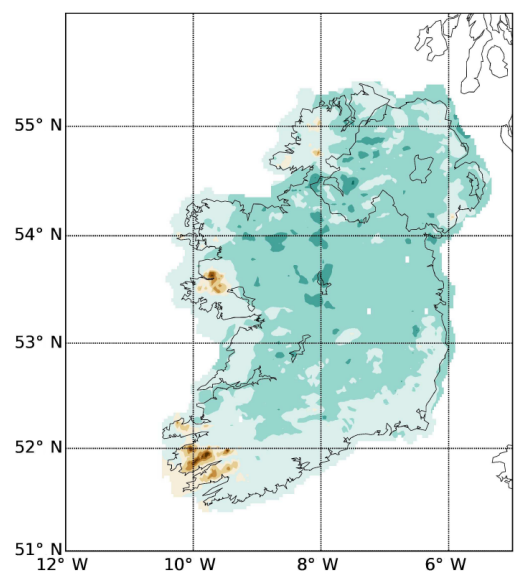

(b)

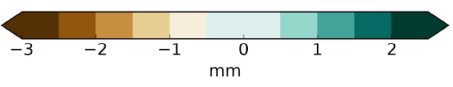

Daily mean bias (DJF)

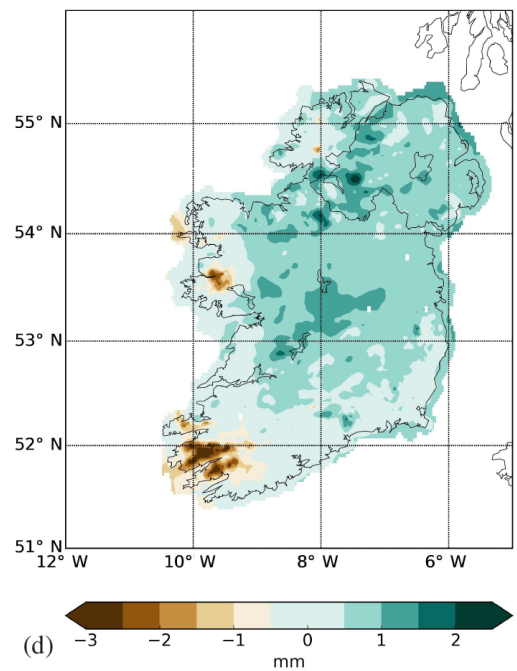

Figure 8. MÉRA minus gridded rainfall observations for the period 1981-2012 by season (a) MAM, (b) JJA, (c) SON and (d) DJF. 


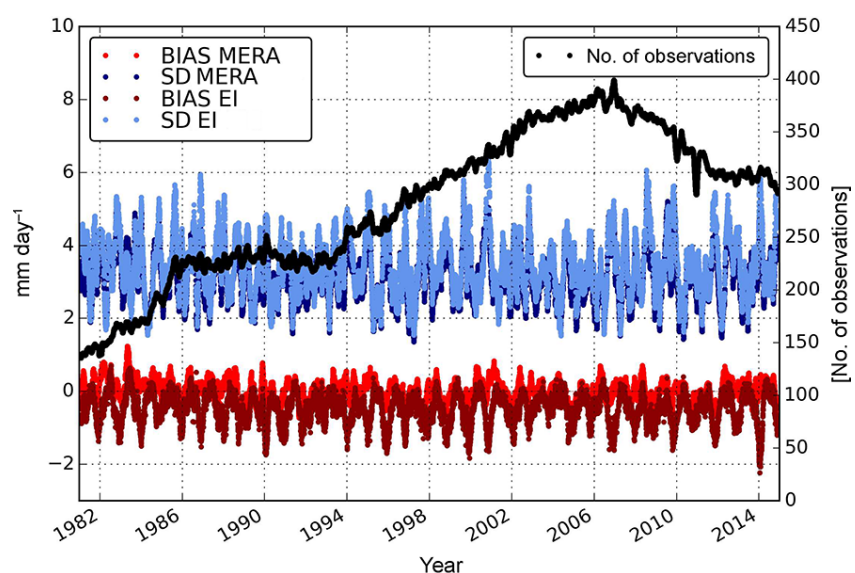

Figure 9. Bias and standard deviation of the residuals in $24 \mathrm{~h}$ precipitation accumulations for MÉRA and ERA-Interim for the period 1981-2014 (2-month running averaging is applied).

provement in the quality of analyses below $200 \mathrm{hPa}$ for the entire reanalysis period.

\section{Forecast Model}

This section summarises an initial validation of MÉRA output including an analysis of the spin-up period, surface parameters, upper-air paramaters and $24 \mathrm{~h}$ rainfall accumulations including comparisons to ERA-Interim where possible. A short discussion on model performance attribution is also included.

\subsection{Model Spin-up}

As described in Sect. 2, a spin-up period of 1 year was deemed necessary, but not proven a priori, to allow deep soil parameters reach an equilibrium. To investigate the length of spin-up required, soil moisture was compared for the yearlong periods of 2000, 2005 and 2010, for both the spinup and corresponding production year. Production output is treated as the "truth". It is estimated that it takes approximately three months for soil moisture at $20 \mathrm{~cm}$ below the surface (Fig. 4a) and nearly an entire year for soil moisture at $300 \mathrm{~cm}$ below the surface (Fig. $4 \mathrm{~b}$ ) to reach equilibrium. Note that the value of $300 \mathrm{~cm}$ is in fact arbitrary and taken to mean the bottom of the soil layer. Soil temperatures reach equilibrium much quicker (e.g. of the order of a few days for soil temperatures $20 \mathrm{~cm}$ below the surface; see Fig. $4 \mathrm{c}$ and d). It is important to note that the soil moisture/temperature values in Fig. 4 were computed by taking areal averages over the land grid points in the domain (sea grid points do not have values).

\subsection{Verification of Surface Parameters}

The forecast model performance was validated by comparing observed surface parameters and MÉRA output. Here we compare MÉRA $3 \mathrm{~h}$ forecasts with synoptic observations available over the MÉRA domain i.e. observations from Ireland, the UK and northern France. In addition, the MÉRA outputs are also compared to the corresponding ERA-Interim reanalysis fields. The inclusion of ERA-Interim data in the comparisons means that only $3 \mathrm{~h}$ forecasts from the 00:00 and 12:00 UTC runs are compared as $3 \mathrm{~h}$ forecasts are unavailable for other ERA-Interim forecasts cycles.

Figure 5 shows the MSLP, $2 \mathrm{~m}$ temperature and $10 \mathrm{~m}$ wind speed verification results for the years 1981-2014. Each subplot shows the bias and standard deviation of the MÉRA and ERA-Interim outputs relative to observations. A 1-month running average is applied in each case for visualisation purposes. The number of observations is also shown in black on each plot. Overall, the results indicate a consistent model performance over the time period. In terms of the standard deviation of the errors, MÉRA out-performs ERA-Interim for MSLP (Fig. 5a), $2 \mathrm{~m}$ temperature (Fig. 5b) and $10 \mathrm{~m}$ wind speed (Fig. 5c). The MÉRA dataset captures the $10 \mathrm{~m}$ wind speeds much better than ERA-Interim (Fig. 5c smaller bias) as expected from a model with improved orographic representation. The biases in $2 \mathrm{~m}$ temperatures relative to observations are lower than the corresponding ERA-Interim biases for the same reason (Fig. 5b). HARMONIE-AROME uses ERA-Interim lateral boundary conditions. This places constraints on the MÉRA large scale pressure patterns. Thus, the differences in biases and standard deviations in MSLP for MÉRA and ERA-Interim are small (Fig. 5a). The obvious shift in biases around 1993 is still under investigation and has not yet been pinned down. However, it is thought to be due to some of the observations for Ireland available on the GTS.

Figure 6a shows a comparison of MÉRA and observed soil temperatures $20 \mathrm{~cm}$ below the surface. This parameter is not included in Met Éireann's operational verification; hence the results presented here represent the first soil temperature verification of HARMONIE-AROME done for Ireland. Soil temperatures are very important for agriculture. It is clear that MÉRA captures the variability in $20 \mathrm{~cm}$ soil temperatures but biases exist of up to $+1^{\circ} \mathrm{C}$ in winter/spring and $-1{ }^{\circ} \mathrm{C}$ in summer/autumn. This is evident in both Fig. $6 \mathrm{a}$ and b. Although there are biases of $\pm 1{ }^{\circ} \mathrm{C}$ the fact that the bulk of the points on the scatter plot in Fig. $6 \mathrm{c}$ is reassuring.

\subsection{Verification of Upper-air Parameters}

The quality of MÉRA upper-air parameters are validated by comparing $12 \mathrm{~h}$ forecast data with radiosonde observations at 12:00 Z each day. A comparison to the equivalent ERA-Interim forecast data was also done. Again, bias and standard deviation are used as a measure of forecast qual- 

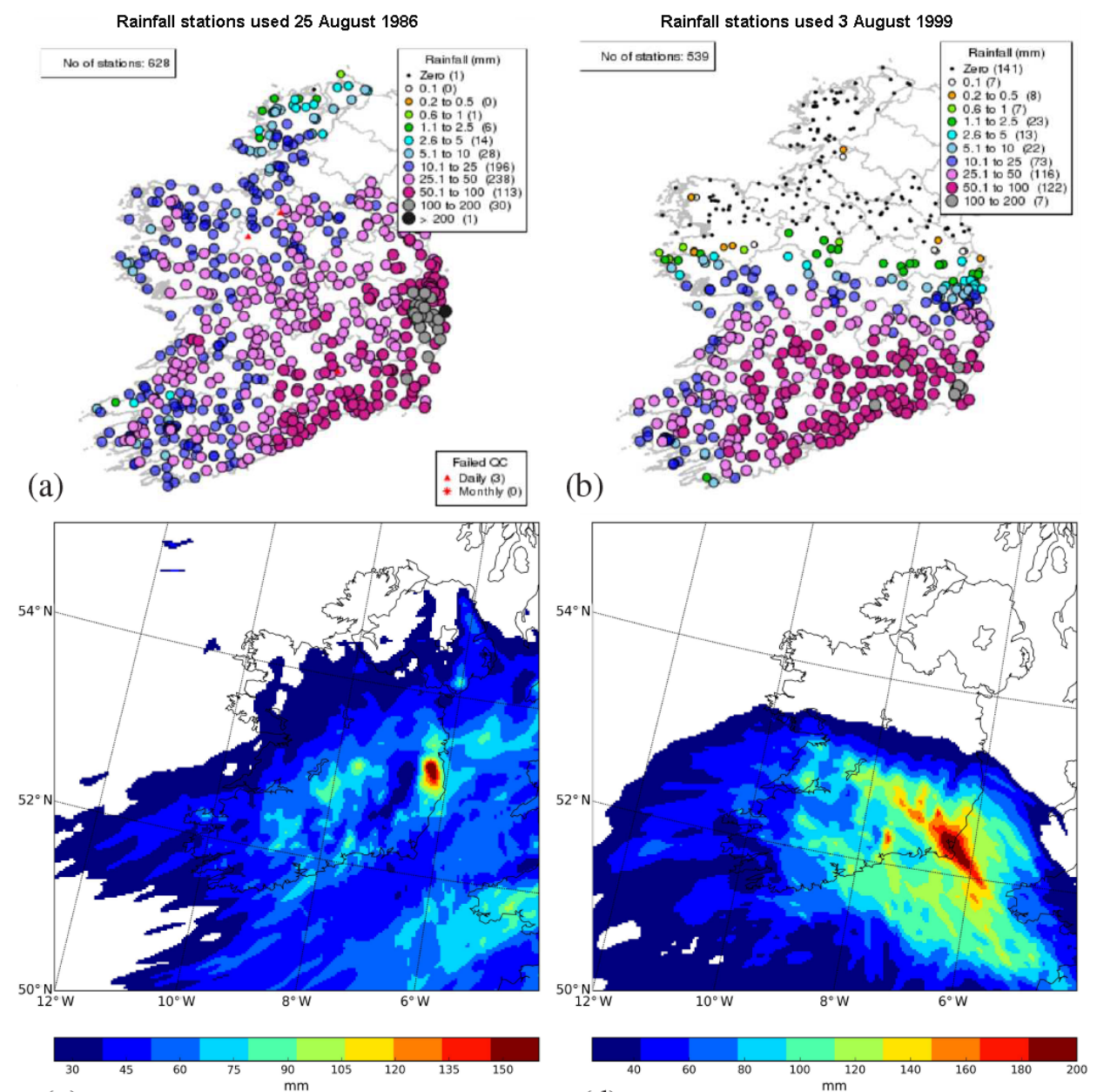

(c)

(d)

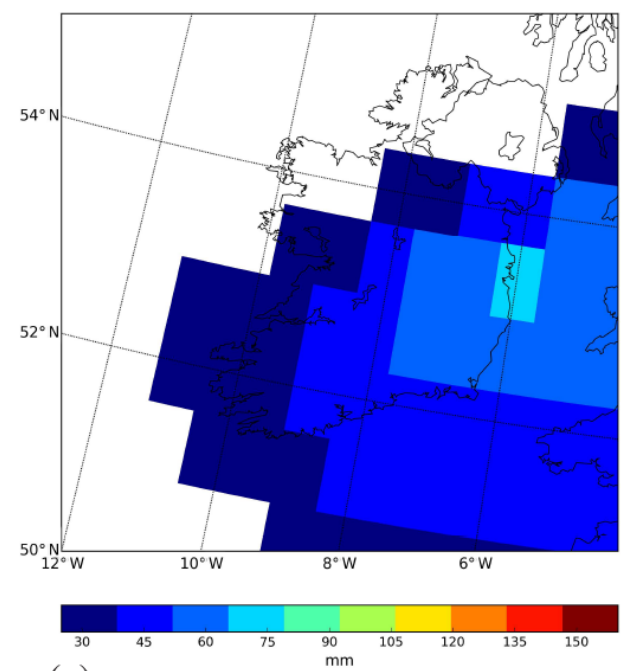

(e)

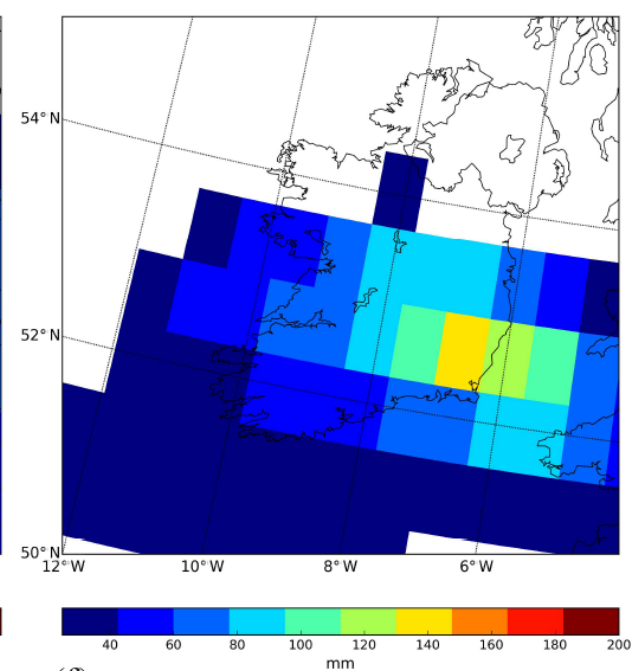

(f)

Figure 10. Hurricane Charley 25/26 August 1986: (a) 09:00 Z, 25 August 1986 to 09:00 Z on 26 August 1986 observed rainfall, (c) $30 \mathrm{~h}$ forecast of the MÉRA rainfall accumulation from 00:00 Z on 25 August 1986, (e) $30 \mathrm{~h}$ forecast of the ERA-Interim rainfall accumulation from 00:00 Z on 25 August 1986. 3 August 1997 bank holiday precipitation (b) 09:00 Z on 4 August 1997 to 09:00 Z on 4 August 1997 observed rainfall (d) MÉRA rainfall accumulation from 00:00 Z on 3 August 1997 to 00:00 Z on 5 August 1997. (f) Era-Interim rainfall accumulation from 00:00 Z on 3 August 1997 to 00:00 Z on 5 August 1997. (e) and (f) are based on successive $24 \mathrm{~h}$ accumulations. 


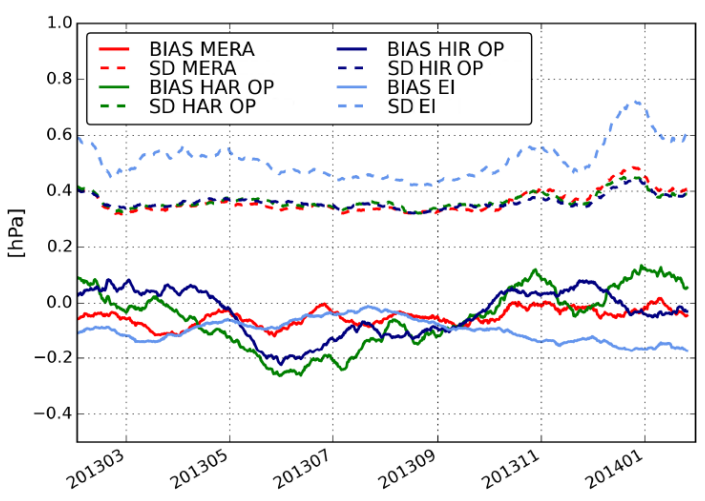

(a)

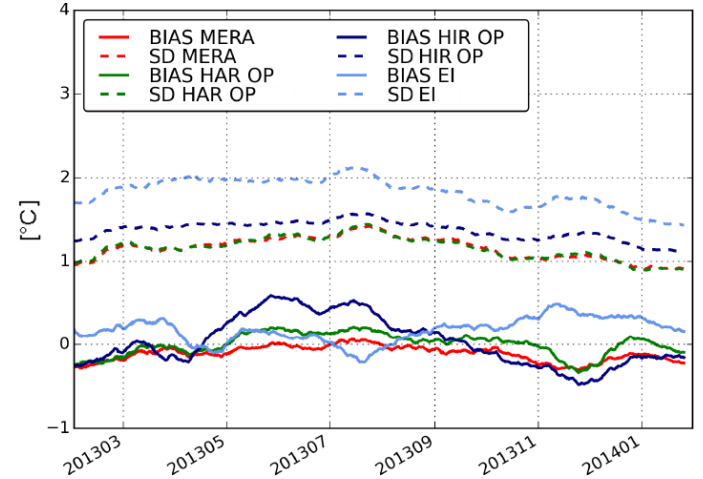

(b)

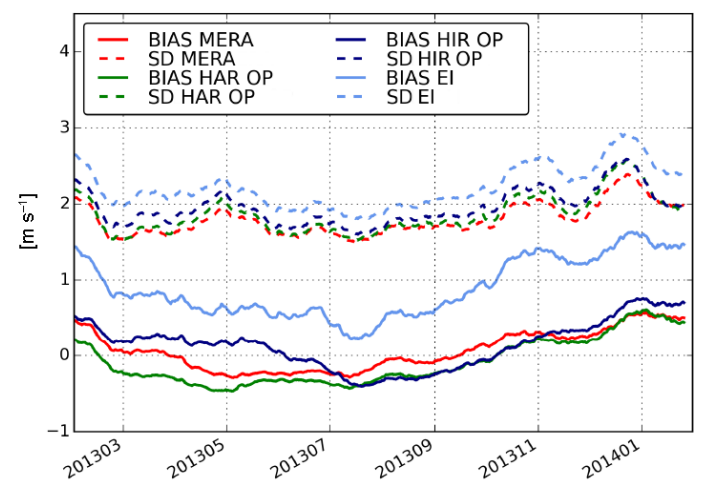

(c)

Year/month

Figure 11. Bias and standard deviations in (a) MSLP, (b) $2 \mathrm{~m}$ temperature, (c) $10 \mathrm{~m}$ wind speed for the following model configurations relative to observations: MÉRA, ERA-Interim (EI), operational HARMONIE-AROME cycle 38h1 (HAR OP) and operational HIRLAM cycle 7.2 (HIR OP). 1-month running averaging is applied.

ity. MÉRA temperature, wind, humidity and geopotential height forecasts compare favourably with ERA-Interim at all heights. In general, for comparisons above $300 \mathrm{hPa}$ and below $850 \mathrm{hPa}$ there are only small differences in bias and standard deviation. However, at levels above $850 \mathrm{hPa}$ and below $300 \mathrm{hPa}$ MÉRA forecasts clearly outperform ERA-Interim; see Fig. 7a and b as typical examples.

\subsection{Verification of $24 \mathrm{~h}$ Rainfall Accumulations}

Precipitation forecasts produced by MÉRA are compared with observations of $24 \mathrm{~h}$ accumulations of precipitation recorded by Met Éireann's voluntary rainfall network (09:00 to $09: 00 \mathrm{Z}$ ). Seasonal mean biases in daily precipitation are mostly positive and within $1 \mathrm{~mm}$ (Whelan and Gleeson, 2016) - see Fig. 8. Larger negative biases over mountains are due to the fact that the $2.5 \mathrm{~km}$ grid spacing in HARMONIE-AROME cannot account for mountain peaks contained within a grid box. Biases in spring (Fig. 8a) are slightly larger than the other seasons, mostly within $2 \mathrm{~mm}$, and are thought to be as a result of magnitude and positional errors in convective rainfall. Fig. 9 shows a time-series of biases and standard deviations of the errors in $24 \mathrm{~h}$ rainfall accumulations (09:00 to 09:00 Z) relative to observations. ERA-Interim forecasts of precipitation are also included on the figure. $36 \mathrm{~h}$ ERA-Interim forecasts only cover the period 00:00 to 06:00 Z. For this reason, the 09:00 to 09:00 Z precipitation forecasts shown for ERA-Interim consist of the sum of the 09:00 to 24:00 Z forecast and the 00:00 to 09:00 Z forecast. As expected, the higher resolution MÉRA shows an improvement over the coarser resolution ERA-Interim, which underestimates precipitation at the Irish climatological stations by up to $\sim 2$ per day. Again, this can be attributed to both model resolution and mesoscale physics parametrizations which resolve convection in MÉRA. Note, however, that the standard deviation of the model errors is similar for MÉRA and ERA-Interim.

The improvement in precipitation forecasts is one of the main advantages of very high resolution reanalyses. Because of this, a qualitative overview of two extreme rainfall case study examples are also included in this section. The first, caused by an offshoot depression from Hurricane Charley on 25/26 August 1986, brought rainfall amounts of over $200 \mathrm{~mm}$ to parts of the east coast of Ireland (Fig. 10a). It was badly forecast by models at the time. The improvement in the $30 \mathrm{~h}$ rainfall forecast by MÉRA (Fig. 10c) compared to ERAInterim (Fig. 10e) is of the order of $100 \mathrm{~mm}$, more over higher orography. Note that the observations cover a $24 \mathrm{~h}$ period from 09:00 $\mathrm{Z}$ on 25 August whereas the MÉRA and ERA-Interim accumulations are for the $30 \mathrm{~h}$ period starting from 00:00 Z on 25 August. While MÉRA data are available for the same period as the observations, only up to $30 \mathrm{~h}$ forecasts are available for ERA-Interim at 00:00 and 12:00 Z. Thus, it requires 2 ERA-Interim forecast cycles to cover the same period as the observations and for simplicity, we chose to show the $30 \mathrm{~h}$ forecast (i.e. 00:00 Z on 25 August to $06: 00 \mathrm{Z}$ on 26 August) for the model performance comparison.

The second case study, heavy rainfall 3/4 August 1997 (bank holiday in Ireland), was also badly forecast by models at the time which failed to forecast any precipitation for Ireland. Instead, accumulations of over $200 \mathrm{~mm}$ were observed over the southern half of the country (Fig. 10b). As for 
the "Hurricane Charley" case, MÉRA performed remarkably well, capturing the extremes, both in terms of intensity and location. The MÉRA and ERA-Interim rainfall totals shown in Fig. 10d and $\mathrm{f}$ represent accumulations of the successive $24 \mathrm{~h}$ totals covering the period 00:00 Z on 3 August 1997 to 00:00 Z on 5 August 1997.

\subsection{Improved Performance Attribution}

While it is clear that HARMONIE-AROME performs better than ERA-Interim for $3 \mathrm{~h}$ forecasts of $2 \mathrm{~m}$ temperature and $10 \mathrm{~m}$ wind speed, how much of the improvement is due to model resolution (and thus better orographic representation) and/or model processes and parametrizations cannot be deduced from Fig. 5. To address this, we compared $3 \mathrm{~h}$ forecasts of MSLP, $2 \mathrm{~m}$ temperature and $10 \mathrm{~m}$ wind speed, for the period February 2013 to February 2014, from MÉRA, ERA-Interim, HARMONIE-AROME cycle 37h1 (current operational version at Met Éireann) and HIRLAM (version 7.2, also operational) (Fig. 11). The Irish operational setup of HARMONIE-AROME cycle $37 \mathrm{~h} 1$ is not configured to use 3D-Var; instead surface data assimilation with upper-air blending is used. 4D-Var data assimilation is used in the operational HIRLAM version 7.2 model (Unden et al., 2002), which is run on a $\sim 10 \mathrm{~km}$ grid. For MSLP, $2 \mathrm{~m}$ temperature and $10 \mathrm{~m}$ wind speed MÉRA and HARMONIE-AROME cycle 37 perform better than HIRLAM which performs better than ERA-Interim. The improvements seen in MÉRA and HARMONIE-AROME cycle 37 relative to HIRLAM are due to a combination of resolution and improved model physics. MÉRA has lower errors in $10 \mathrm{~m}$ wind speeds (Fig. 11c) than the operational HARMONIE-AROME both due to the use of 3D-Var and the fact that the surface drag coefficient was tuned. Biases and standard deviations in MSLP (Fig. 11a) and $2 \mathrm{~m}$ temperatures (Fig. 11b) for MÉRA and HARMONIE-AROME cycle 37 are comparable but again are noticably better than HIRLAM and ERA-Interim.

\section{Conclusions}

In this article we have described how the HARMONIEAROME model has been used to produce a climate reanalysis dataset MÉRA for Ireland. We have carried out a preliminary evaluation of the dataset and shown that the HARMONIE-AROME data assimilation system and forecast model perform well and consistently when compared with point observations. MÉRA's advantage over ERA-Interim was also illustrated. A more thorough validation of the entire dataset is underway, with the aim of quantifying all biases in the dataset. This will enable improvements to be made to Met Éireann's operational NWP suite and will also help in the design of a proposed high resolution ensemble forecasting system.

MÉRA is the highest resolution, freely available reanalysis dataset covering Ireland and will have uses in re- search, food and agriculture, renewable energy, ecology, planning, economics and hydrology. A future regional reanalysis for Ireland would gain from using the latest version of HARMONIE-AROME, a larger domain, the assimilation of more observation types and the generation of an ensemble of reanalyses with ensemble data assimilation. The use of ERA-5 for lateral boundary conditions as well as a coupled ocean-atmosphere system should also produce an improved reanalysis dataset.

Data availability. The datasets have been archived at Met Éireann. There is currently no publicly available method for data access so Met Éireann should be contacted for dataset access.

Author contributions. Emily Gleeson and Eoin Whelan wrote the paper and carried out the analysis. Eoin Whelan prepared the MÉRA configuration and carried out the simulations. John Hanley checked the input observations and output gridded data.

Competing interests. The authors declare that they have no conflict of interest.

Acknowledgements. International HIRLAM-B and ALADIN programmes. We would like to thank Bing Li and Ray McGrath for their help preparing the observations used in the MÉRA project. We would also to thank the two anonymous referees and the editor for their useful suggestions which have improved the content of the paper.

Edited by: A. K. Kaiser-Weiss

Reviewed by: two anonymous referees

\section{References}

Bengtsson, L., Andrae, U., Aspelien, T., Batrak, Y., Calvo, J., de Rooy, W., Gleeson, E., Hansen-Sass, B., Homleid, M., Hortal, M., Ivarsson, K.-I., Lenderink, G., Niemelä, S., Nielsen, K. P., Onvlee, J., Rontu, L., Samuelsson, P., Muñoz, D. S., Subias, A., Tijm, S., Toll, V., Yang, X., and Ødegaard Køltzow, M.: The HARMONIE-AROME model configuration in the ALADINHIRLAM NWP system, Mon. Weather Rev., doi:10.1175/MWRD-16-0417.1, 2017.

Berre, L.: Estimation of Synoptic and Mesoscale Forecast Error Covariances in a Limited-Area Model, Mon. Weather Rev., 128, 644-667, doi:10.1175/15200493(2000)128<0644:EOSAMF>2.0.CO;2, 2000.

Bollmeyer, C., Keller, J. D., Ohlwein, C., Wahl, S., Crewell, S., Friederichs, P., Hense, A., Keune, J., Kneifel, S., Pscheidt, I., Redl, S., and Steinke, S.: Towards a high-resolution regional reanalysis for the European CORDEX domain, Q. J. Roy. Meteor. Soc., 141, 1-15, doi:10.1002/qj.2486, 2015.

Bromwich, D., Kuo, Y.-H., Serreze, M., Walsh, J., Bai, L.-S., Barlage, M., Hines, K., and Slater, A.: Arctic system reanalysis: call 
for community involvement, Eos, Transactions American Geophysical Union, 91, 13-14, 2010.

Brousseau, P., Berre, L., Bouttier, F., and Desroziers, G.: Background-error covariances for a convective-scale dataassimilation system: AROME-France 3D-Var, Q. J. Roy. Meteor. Soc., 137, 409-422, doi:10.1002/qj.750, 2011.

Burgers, G., Baas, P., and van den Brink, H.: Towards an extreme wind climatology for The Netherlands based on downscaling ERA-Interim with the HARMONIE-AROME high-resolution model, poster presented at EGU 2013, Vienna, 2013.

Dahlgren, P., Landelius, T., Kållberg, P., and Gollvik, S.: A high-resolution regional reanalysis for Europe. Part 1: Threedimensional reanalysis with the regional HIgh-Resolution Limited-Area Model (HIRLAM), Q. J. Roy. Meteor. Soc., 142, 2119-2131, doi:10.1002/qj.2807, 2016.

Davies, T.: Lateral boundary conditions for limited area models, Q. J. Roy. Meteor. Soc., 140, 185-196, doi:10.1002/qj.2127, 2013.

Dee, D. P., Uppala, S. M., Simmons, A. J., Berrisford, P., Poli, P., Kobayashi, S., Andrae, U., Balmaseda, M. A., Balsamo, G., Bauer, P., Bechtold, P., Beljaars, A. C. M., van de Berg, L., Bidlot, J., Bormann, N., Delsol, C., Dragani, R., Fuentes, M., Geer, A. J., Haimberger, L., Healy, S. B., Hersbach, H., Hólm, E. V., Isaksen, L., Kllberg, P., Köhler, M., Matricardi, M., McNally, A. P., Monge-Sanz, B. M., Morcrette, J.-J., Park, B.-K., Peubey, C., de Rosnay, P., Tavolato, C., Thépaut, J.-N., and Vitart, F.: The ERA-Interim reanalysis: configuration and performance of the data assimilation system, Q. J. Roy. Meteor. Soc., 137, 553-597, doi:10.1002/qj.828, 2011.

Fischer, C., Montmerle, T., Berre, L., Auger, L., and Şfănescu, S. E.: An overview of the variational assimilation in the ALADIN/France numerical weather-prediction system, Q. J. Roy. Meteor. Soc., 131, 3477-3492, doi:10.1256/qj.05.115, 2005.

Fleming, R., Kaneshige, T., and McGovern, W.: The Global Weather Experiment 1. The observational phase through the first special observing period, B. Am. Meteorol. Soc., 60, 649-661, 1979.

Gallagher, S., Tiron, R., Whelan, E., Dias, F., and McGrath, R.: The nearshore wind and wave energy potential of Ireland: A high resolution assessment of availability and accessibility, Renew. Energ., 88, 494-516, doi:10.1016/j.renene.2015.11.010, 2016.

Harris, L. M. and Durran, D. R.: An Idealized Comparison of OneWay and Two-Way Grid Nesting, Mon. Weather Rev., 138, 2174 2187, doi:10.1175/2010MWR3080.1, 2010.

Hersbach, H. and Dee, D.: ERA5 reanalysis is in production, ECMWF Newsletter 147, ECMWF, http://www.ecmwf.int/en/ elibrary/16299-newsletter-no147-sprin\%g-2016 (last access: 24 March 2017), 2016.

Hersbach, H., Peubey, C., Simmons, A., Poli, P., Dee, D., and Berrisford, P.: ERA-20CM: a twentieth century atmospheric model ensemble, Shinfield Park, Reading, 2013.

Hollweg, H. D., Böhm, U., Fast, I., Hennemuth, B., Keuler, K., Keup-Thiel, E., Lautenschlager, M., Legutke, S., Radtke, K., Rockel, B., Schubert, M., Will, A., Woldt, M., and Wunram, C.: Ensemble Simulations over Europe with the Regional Climate Model CLM forced with IPCC AR4 Global Scenarios, Tech. Rep. 3, Max-Planck Institute for meteorology, Model and Data, 2008.

Kalnay, E., Kanamitsu, M., Kistler, R., Collins, W., Deaven, D., Gandin, L., Iredell, M., Saha, S., White, G., Woollen, J., Zhu,
Y., Leetmaa, A., Reynolds, R., Chelliah, M., Ebisuzaki, W., Higgins, W., Janowiak, J., Mo, K., Ropelewski, C., Wang, J., Jenne, R., and Joseph, D.: The NCEP/NCAR 40-Year Reanalysis Project, B. Am. Meteorol. Soc., 77, 437-471, doi:10.1175/15200477(1996)077<0437:TNYRP>2.0.CO;2, 1996.

Kar, S., Routray, A., and Mali, P.: South Asian regional reanalysis, in: 4th World Climate Research Programme International Conference on Reanalyses, 2016.

Kasahara, A., Mizzi, A., and Donner, L.: Impact Of Cumulus Initialization on the Spinup of Precipitation Forecasts in the Tropics, Mon. Weather Rev., 120, 1360-1380, doi:10.1175/15200493(1992)120<1360:IOCIOT>2.0.CO;2, 1992.

Klein Tank, A.: EURO4M: monitoring weather and climate extremes in Europe, in: 10th EMS Annual Meeting, 10th European Conference on Applications of Meteorology (ECAM) Abstracts, 13-17 September 2010 in Zürich, Switzerland, http:// meetings.copernicus.org/ems2010/ (last access: 24 March 2017), id. EMS2010-202, vol. 1, p. 202, 2010.

Kobayashi, S., Ota, Y., Harada, Y., Ebita, A., Moriya, M., Onoda, H., Onogi, K., Kamahori, H., Kobayashi, C., Endo, H., Miyaoka, K., and Takahashi, K.: The JRA-55 Reanalysis: General Specifications and Basic Characteristics, J. Meteorol. Soc. Jpn., 93, 5-48, doi:10.2151/jmsj.2015-001, 2015.

Luhamaa, A., Kimmel, K., Männik, A., and Rõõm, R.: High resolution re-analysis for the Baltic Sea region during 1965-2005 period, Clim. Dynam., 36, 727-738, doi:10.1007/s00382-0100842-y, 2011.

Masson, V., Le Moigne, P., Martin, E., Faroux, S., Alias, A., Alkama, R., Belamari, S., Barbu, A., Boone, A., Bouyssel, F., Brousseau, P., Brun, E., Calvet, J.-C., Carrer, D., Decharme, B., Delire, C., Donier, S., Essaouini, K., Gibelin, A.-L., Giordani, H., Habets, F., Jidane, M., Kerdraon, G., Kourzeneva, E., Lafaysse, M., Lafont, S., Lebeaupin Brossier, C., Lemonsu, A., Mahfouf, J.-F., Marguinaud, P., Mokhtari, M., Morin, S., Pigeon, G., Salgado, R., Seity, Y., Taillefer, F., Tanguy, G., Tulet, P., Vincendon, B., Vionnet, V., and Voldoire, A.: The SURFEXv7.2 land and ocean surface platform for coupled or offline simulation of earth surface variables and fluxes, Geosci. Model Dev., 6, 929-960, doi:10.5194/gmd-6-929-2013, 2013.

Mesinger, F., DiMego, G., Kalnay, E., Mitchell, K., Shafran, P. C., Ebisuzaki, W., Jović, D., Woollen, J., Rogers, E., Berbery, E. H., Ek, M. B., Fan, Y., Grumbine, R., Higgins, W., Li, H., Lin, Y., Manikin, G., Parrish, D., and Shi, W.: North American Regional Reanalysis, B. Am. Meteorol. Soc., 87, 343-360, doi:10.1175/BAMS-87-3-343, 2006.

Poli, P., Hersbach, H., Tan, D. G. H., Dee, D., Thepaut, J.-J., Simmons, A., Peubey, C., Laloyaux, P., Komori, T., Berrisford, P., Dragani, R., Trémolet, Y., Hólm, E. V., Bonavita, M., Isaksen, L., and Fisher, M.: The data assimilation system and initial performance evaluation of the ECMWF pilot reanalysis of the 20thcentury assimilating surface observations only (ERA-20C), Shinfield Park, Reading, 2013.

Rienecker, M., Suarez, M., Gelaro, R., Todling, R., Bacmeister, J., Liu, E., Bosilovich, M., Schubert, S., Takacs, L., Kim, G., Bloom, S., Chen, J., Collins, D., Conaty, A., da Silva, A., Gu, W., Joiner, J., Koster, R., Lucchesi, R., Molod, A., Owens, T., Pawson, S., Pegion, P., Redder, C., Reichle, R., Robertson, F., Ruddick, A., Sienkiewicz, M., and Woollen, J.: MERRA: NASA's Modern-Era Retrospective Analysis for Research and 
Applications, J. Climate, 24, 3624-3648, doi:10.1175/JCLI-D11-00015.1, 2011.

Sánchez Arriola, J., Lindskog, M., Thorsteinsson, S., and Bojarova, J.: Variational Bias Correction of GNSS ZTD in the HARMONIE Modeling System, J. Appl. Meteorol. Clim., 55, 12591276, doi:10.1175/JAMC-D-15-0137.1, 2016.

Seity, Y., Brousseau, P., Malardel, S., Hello, G., Bénard, P., Bouttier, F., Lac, C., and Masson, V.: The AROME-France ConvectiveScale Operational Model, Mon. Weather Rev., 139, 976-991, doi:10.1175/2010MWR3425.1, 2011.

Stepek, A., Savenije, M., van den Brink, H., and Wijnant, I.: Validation of KNW atlas with publicly available mast observations (Phase 3 of KNW project), Tech. rep., KNMI Technical Report TR352, 2015.

Taillefer, F.: CANARI - Technical Documentation - Based on ARPEGE cycle CY25T1 (AL25T1 for ALADIN), Tech. rep., CNRM/GMAP, 2002.

Taylor, K. E., Stouffer, R. J., and Meehl, G. A.: An Overview of CMIP5 and the Experiment Design, B. Am. Meteorol. Soc., 93, 485-498, doi:10.1175/BAMS-D-11-00094.1, 2012.

UERRA: UERRA Newsletter Number 3, Newsletter 3, http://www. uerra.eu/182-newsletter-no-3-january-2017.html, last access: 27 March 2017.

Unden, P., Rontu, L., Järvinen, H., Lynch, P., Calvo, J., Cats, G., Cuxart, J., Eerola, K., Fortelius, C., Garcia-Moya, J. A., Jones, C., Geert, Lenderlink, G., Mcdonald, A., Mcgrath, R., Navascues, B., Nielsen, N. W., Degaard, V., Rodriguez, E., Rummukainen, M., Sattler, K., Sass, B. H., Savijarvi, H., Schreur, B. W., Sigg, R., and The, H.: HIRLAM-5 Scientific Documentation, http://hirlam.org/index.php/hirlam-documentation/ doc_download/308-unden-et-al-2002 (last access: 28 March 2017), 2002.
Uppala, S. M., Kållberg, P. W., Simmons, A. J., Andrae, U., Bechtold, V. D. C., Fiorino, M., Gibson, J. K., Haseler, J., Hernandez, A., Kelly, G. A., Li, X., Onogi, K., Saarinen, S., Sokka, N., Allan, R. P., Andersson, E., Arpe, K., Balmaseda, M. A., Beljaars, A. C. M., Berg, L. V. D., Bidlot, J., Bormann, N., Caires, S., Chevallier, F., Dethof, A., Dragosavac, M., Fisher, M., Fuentes, M., Hagemann, S., Hólm, E., Hoskins, B. J., Isaksen, L., Janssen, P. A. E. M., Jenne, R., Mcnally, A. P., Mahfouf, J.-F., Morcrette, J.-J., Rayner, N. A., Saunders, R. W., Simon, P., Sterl, A., Trenberth, K. E., Untch, A., Vasiljevic, D., Viterbo, P., and Woollen, J.: The ERA-40 re-analysis, Q. J. Roy. Meteor. Soc., 131, 29613012, doi:10.1256/qj.04.176, 2005.

Warner, T. T., Peterson, R. A., and Treadon, R. E.: A Tutorial on Lateral Boundary Conditions as a Basic and Potentially Serious Limitation to Regional Numerical Weather Prediction, B. Am. Meteorol. Soc., 78, 2599-2617, doi:10.1175/15200477(1997)078<2599:ATOLBC>2.0.CO;2, 1997.

Whelan, E. and Gleeson, E.: Met Éireann High Resolution Reanalysis for Ireland, in: Proceedings of the National Hydrology Seminar 2016, Office of Public Works, 2016. 